University of Nebraska - Lincoln

DigitalCommons@University of Nebraska-Lincoln

Faculty Publications -- Department of English

English, Department of

2017

George Eliot in Romantic Biofiction

Beverley Rilett

Follow this and additional works at: https://digitalcommons.unl.edu/englishfacpubs

Part of the Comparative Literature Commons, English Language and Literature Commons, Modern Literature Commons, and the Reading and Language Commons

This Article is brought to you for free and open access by the English, Department of at DigitalCommons@University of Nebraska - Lincoln. It has been accepted for inclusion in Faculty Publications -Department of English by an authorized administrator of DigitalCommons@University of Nebraska - Lincoln. 


\title{
George Eliot in Romantic Biofiction
}

\author{
Beverley Park Rilett
}

\begin{tabular}{c}
\hline The Honeymoon \\
Dinitia Smith \\
Other Press \\
www.otherpress.com \\
415 Pages; Print, \$26.95 \\
\hline
\end{tabular}

Dinitia Smith's The Honeymoon is the first complete biofiction of the woman enduringly known by her masculine pen name, George Eliot. It tells the story of a precocious provincial English girl who challenges the conventions of her middleclass upbringing as she pursues a writing career in Victorian London, moves in with an alreadymarried man, becomes one of the greatest living British novelists, and then marries John Cross, a man twenty years her junior whom she'd long called "nephew." Whether or not Eliot's brief marriage to Cross constituted a "happy ending" depends on how you interpret the harrowing incident that took place during their honeymoon in Venice. This is the mystery of the novel, which I will not spoil here.

Parts of Eliot's life have been represented in fiction in several other works, but no novelist before Smith has attempted to recreate Eliot's

Published in American Book Review, Volume 39, Number 1, November/December 2017, pp. 15-30 (Review)

DOI: $10.1353 /$ abr.2017.0136 
whole life. The Honeymoon is thus an important contribution both to the biographical record of George Eliot and to the stillemerging genre of biofiction, in which a novelist draws from traditional biographical sources to create a new version of the life of a historical figure, usually paying particular attention to the subject's interiority. In a brief prefatory "Note to the Reader," Smith clearly states that she has written "a novel, a product of my imagination inspired by the life and writings of George Eliot" in order to depict Eliot's "inner

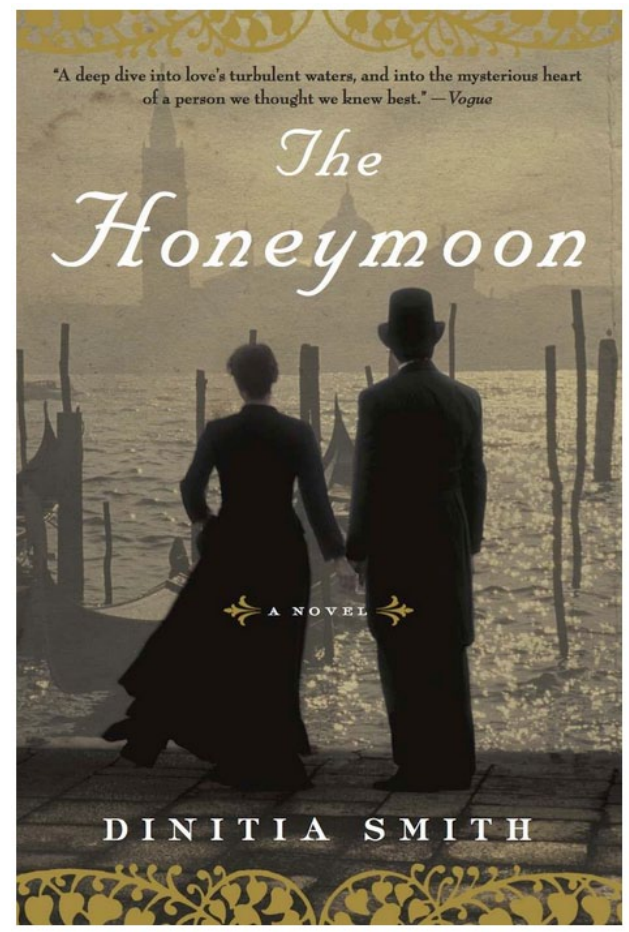
world as she lived out her life."

The Honeymoon begins a few months before Eliot's death. It opens with the newlywed couple approaching Venice, the site of their illfated honeymoon, then weaves this story in short chapters between longer ones that reveal Eliot's past. This double narrative structure helps to maintain the novel's dramatic tension and to illustrate how Eliot's character responded to successive challenges. Smith acknowledges that John Walter Cross was "the most difficult character to track" in the existing biographical record, but I believe this paucity of information ultimately freed Smith to fashion him as Eliot's foil, a man with complex motivations and secrets he keeps from his new wife. Her representation of Cross is one of the greatest strengths of the novel; his character unfolds in surprising new ways not previously depicted in fiction or biography. As the past catches up with the present, the honeymoon experience in general and Cross in particular come to symbolize how little we really know about other people, even those closest to us.

In her foreword "Note to the Reader," Smith asserts her prerogative as a novelist to alter some biographical details to suit artistic purposes. She explains that she has "sometimes transposed phrases from Eliot's novels, letters, and journals" and that "[f]or the sake of clarity" she has taken "some dramatic license in the chronology." Transmutations 
of this sort represent an expected practice of biofiction authors who regularly subordinate biographical facts to their creative vision. Smith not only specifies which biographical elements she has changed, she also adds, "There is nothing in this story that I know with certainty did not happen," a curious statement that suggests her biofiction is essentially authentic. In an afterword entitled "Fact into Fiction: A Bibliographical Essay on Writing The Honeymoon," Smith further details the sources of her research into the life and times of her subject. The description of this diligent research serves to convince readers that they can trust Smith's depiction of Eliot as a kind of biographic truth. The usual distinctions between biofiction and biography are nearly erased.

The honeymoon story is the most dramatic of the novel's two narratives but the protagonist's backstory-Eliot's recollection of past events and relationships-actually dominates the novel. Smith's version of Eliot's life is closest to the conclusions of several pre-feminist biographers, including Charles Bray, Gordon Haight, and Kathleen Adams, all of whom Smith acknowledges as sources. All regard Eliot as needy, lovelorn, and insecure, entirely dependent on the men in her life. Smith's Eliot, for example, repeatedly "lets" men make love to her and later berates herself with questions such as, "Why didn't she have a solid core that would enable her to survive without the love of a man?" She is even described as having "a need for self-punishment." Before meeting Lewes, she "had thought phrenology was silly, but oh, how true those words were. 'Not fitted to stand alone."” Consequently, Smith's Eliot believes herself "a failure, trapped by her unmet need to be loved. It was the need of a wounded child." She agrees to marry Cross because he had become "her protector, her encourager, and she needed him now," but during Cross's illness, she thinks "Where was George [Lewes] now, when she needed him?" and "How would she ever finish [a new novel] without George to read every word and prop her up?" Smith's protagonist neither conquers her fears nor grows out of her dependency.

As Smith explicitly indicates, her fragile protagonist is based on creditable biographical sources. Because she makes a case for the authenticity of her portrayal of Eliot, readers may be surprised to find her interpretation differs markedly from the most prominent feminist biographers, including Rosemarie Bodenheimer, Rosemary Ashton, and Nancy Henry, who emphasize the strength of this brilliant, 
successful author in the face of her life's adversity. The self-disparagement and self-doubt evident in Eliot's letters, for example, may be read as the intentional or partly conscious posturing of a woman trying to project an image of unambitious humility in order to defend herself against her damaged reputation. Though Smith's version of Eliot is no longer prominent in biographical scholarship, readers should bear in mind that there are more than thirty-five full-life biographies of Eliot's life, and each of them explains Eliot's complex and often contradictory behavior differently.

Smith has made some other intriguing biographical choices. For Smith, Eliot is a romantic, passionate, and unequivocally heterosexual woman who becomes emotionally and physically involved with various men throughout her life. While some biographers conclude that Eliot was probably sexually active with most (if not all) of these men, others, including Barbara Hardy, contend she was likely a virgin when she met Lewes. In The Honeymoon, the notion that someone Eliot knows might be a so-called "Nancy boy" is unthinkable, however twentyfirst century biographers frequently acknowledge Eliot's awareness and acceptance of same-sex desire. Some even suggest that same-sex desire played a part of Eliot's close friendships with Sara Hennell, Maria Congreve, and Edith Simcox, none of whom appears in Smith's novel. Smith also eliminates Eliot's deep friendship with portrait artist Francois d'Albert Durade. As a fiction writer, Smith has the freedom and perhaps the obligation to project a singular, complete vision of Eliot's life story as she imagines it, even if it means sacrificing some characters. Excluding these relationships from The Honeymoon allows Smith to present her heroine in her own way, unambiguously, without having to account for variant critical insights.

Readers familiar with Eliot's biography may notice the elimination of a few major players, but I would argue that these choices serve the consistency, unity, and pacing of Smith's novel. Moreover, The Honeymoon not only presents a cohesive and sympathetic insight into the life and mind of a fascinating woman, it also demonstrates Smith's excellent grasp of the historical period. Smith visited the novel's various settings and immersed herself in Victorian literature, art, music, architecture, and social history in order to show them accurately. The food they ate, the way they decorated their homes, the music they listened to, the vehicles they rode in, and the myriad details of middleclass Victorian life are seamlessly woven into the narrative. Various 
settings, including London, the English Midlands, Venice, and the German spa towns, are beautifully rendered. Smith's erudite descriptions help us visualize these places and teach us something of their social and geographic history.

Eliot's life continues to generate new biographies that attempt to explain her contradictions. Critics still debate what may seem to be the most basic of assumptions, including how "Christian" she was, how "feminist" she was, the nature of her sexuality, the nature of her relationship to the men in her life, and the amount of autobiography in her fiction, to name a few. Traditional biographers build complicated cases for their interpretations while informing readers that other views exist. Some of us relish the scholarly deliberations and the copious footnotes that support them, but the general reader probably does not.

Dinitia Smith has done what has been needed for a long time-she has made George Eliot's life story accessible to a wider audience than those seeking a traditional biography. Readers already knowledgeable about Eliot will appreciate the way Smith has synthesized copious biographical and historical materials to form a sensitive, psychologically realistic portrait of the artist. As she explores the apparently "tragic ending to what was an essentially noble life," Smith offers insight into the private fragility of one of the most famous and powerfully influential authors in England. Those who do not yet know what happened during Eliot's honeymoon in Venice will find the story and its backstory a compelling page-turner. Whether or not this biofiction leads readers to other biographical and critical sources, on its own it is a wonderful introduction to the life of a novelist who had a devoted following in her own time that continues today.

Beverley Park Rilett is a Research Assistant Professor in English at the University of Nebraska- Lincoln. Her teaching and research specialty is nineteenth- and early twentieth-century British literature and culture. Her most recent articles appear in the journals George Eliot-George Henry Lewes Studies and the Walt Whitman Quarterly Review. Rilett is currently completing a revisionist biography of George Eliot and beginning a George Eliot digital archive project. 